\title{
Poultry Welfare Scenario in South America: Norms and Regulations
}

Review

\section{-Author(s)}

Silva RBTR ${ }^{1,3}$

Nääs $\mid A^{2}$

Broom DM²

O'Driscoll K²

1 College of Agric. Eng. Campinas, SP, Brazil.

2 Universidade Paulista - UNIP.

3 Centre for Animal Welfare and Anthrozoology. Department of Veterinary Medicine. University of Cambridge.

Madingley Road, Cambridge CB3 OES, U.K.

\section{mail Adress}

Raquel B. T. R. da Silva

College of Agric. Eng.

13.083-970.Campinas, SP, Brazil.

E-mail: raquelbaracat@gmail.com

\section{-Keywords}

Competitiveness, developing countries, international trade, welfare policies.

\begin{abstract}
Animal welfare related issues have been intensely discussed in recent years as a consequence of changes in public attitudes and regulatory reforms that are taking place in many countries. A combination of public opinion pressure and trade policy has driven requirements for regulation and the World Trade Organization (WTO) assigned the World Organization for Animal Health (OIE) to develop guidelines that could be used as international standards. However, trade disputes related to animal welfare are not likely to be resolved under the auspices of OIE, and access to international markets may be questioned in a way that does not necessarily reflect attitudes to animal production in emerging economies, such as those in South America. This paper presents an overall view of basic welfare issues and points out specific items related to the present scenario of norms and regulations that are being implemented in South America, where the growing poultry industry is an important economic activity.
\end{abstract}

\section{INTRODUCTION}

Animal welfare concerns are not new. Some of the ancient religious rules for slaughtering animals were originally intended to reduce animal pain. Many religions, including those of Native Americans, Hinduism, and Australian aboriginal tradition, have held particular animals to be sacred, and have devised specific rules as to whether and how such animals were to be used for food or service (Broom, 2003). However, during the last twenty years consumer groups, particularly in industrialised nations, have started to exert public pressure on governments and producers as to animal welfare (Broom, 2001; 2002). Animal welfare is a term used in society in relation to ethical concern regarding the treatment of animals and it has lately called public global attention. However, farmers believe that this can be considered as trade restriction.

The economic role of farm animals is to deliver benefits to consumers in terms of food and other products (McInerney, 2004). Even though the primary role of agricultural animals is for human food consumption, and the level of inputs such as fodder, housing, disease control and environment management has reached a high degree of technologydriven success, the production process has been pushed to the biological limits and it is an increasing challenge to deal with the consequences for animal welfare as perceived by the public (Dawkins, 2003; Mc Inerney, 2004). The welfare of an animal may be affected by a variety of factors such as nutrition, pathogens, physical damage, inadequate housing conditions, harsh treatment, etc. (Broom \& Fraser 2007).

Poultry production is important income source in South American countries and chicken meat is relatively cheap. Brazil is amongst the 
world's five largest poultry meat producers (Figure 1 ), and the neighbouring countries have significant production, which is proportional to their capacity of producing or importing grain (Figure 2). In this review, welfare issues related to poultry production in South American countries are discussed, as well as the norms and regulations proposed by associations and government in order to face trade requirements.



Figure 1 - The world's largest poultry production countries and their percentages of meat production worldwide. Source: ABEF (2008).

\section{GLOBAL IMPROVEMENT OF ANIMAL WELFARE}

Animal production systems in developing countries have been pressured to meet the increasing demands of their growing population, at the expense of water pollution, land degradation and ultimately deforestation (Bellaver \& Bellaver, 1999). The welfare of animals has not often been considered. However, the attitudes of consumers now have to be taken into account or products may not be purchased (Broom, 2006). The concern with improvements in animal production needs to include a wide variety of aspects of sustainability, including animal welfare (Broom, 2003). Although the World Trade Organization (WTO) has not explicitly recognised animal welfare as a legitimate cause for impeding trade, the EU has advocated the issue of animal welfare on the agenda for international negotiations. Over 180 member countries of the World Organization for Animal Health (OIE) have agreed on general animal welfare guidelines relative to slaughter, transportation and the sacrifice of animals for disease control purposes. In the coming years the OIE is likely to take a considerable amount of time to establish comprehensive global animal welfare standards at farm level. In the meantime, meat-producing countries will not have specific international guidance other than recognized good practice manuals or standards required by retail food companies.

Laws, norms and regulations dealing with farm animal welfare can have an important economic impact on production costs and on international trade. Animal welfare laws regulating the treatment of farm animals used for agricultural production have been established in most South American countries for some time, and are part of the legal code of a number of nations, even though some laws simply prohibit cruelty to animals, including farm animals. Many industrialised countries have generated government-regulated reform, mainly due to consumers' demands, sometimes reinforced by private certification agencies. As a direct consequence the demands for better animal welfare have increased together with other issues regarding international
Figure 2 - The most important poultry meat production countries in South America and their respective annual production. Source: ASPROCER (2009); APA (2009); EL COMERCIO (2008); FENAVI (2009); FENAV (2009). 
trade, such as the ban of child labour and the adoption of environmentally-friendly production (EUREPGAP, 2005; van Horne \& Achterbosch, 2008).

Traditionally, animal agriculture was widely viewed as a form of independent enterprise involving close relationships between people, animals and nature. As animal agriculture grew, animal production has come to be perceived, rightly or wrongly, more like an industrial, technological and corporate-owned activity. This change in public perception has resulted in greater ethical questioning of food production and a greater willingness to see standards imposed on the industry. The different views on welfare arise partly because people differ in the value they attach to it. The intensive producer sees high levels of production and feed efficiency as so important that it warrants some restriction of movement. The free-range producer sees access to the outdoors as so important that it warrants some exposure to harsh weather. It would be comforting to think that science could arbitrate among these different value-based views of what should be provided for animals. In reality, a tradition of scientific research has grown up around each of the different views (Mitchell, 2001). A relevant and objective area of science concerns how to assess the welfare of individual animals (Broom \& Fraser, 2007).

Handling procedures, stocking density, free access to feed and water, adequate housing and air quality are well documented in literature, and have been regulated by several countries (Albright \& Arave 1997; Boivin et al., 1992; Silva, 2001; Wathes et al., 2000, Pawelek \& Croney, 2003). Comprehensive knowledge on farm animals' behavioural activities is important for the improvement of animal husbandry, and related information has been used for establishing appropriate directives and legislations for animal welfare worldwide (Duncan et al., 1991; Snowdon, 1999; Puma et al., 2001; Dawkins, 2003). Some management items stated in specific regulations from the EU, such as flock density or ammonia concentration, do not necessarily reflect the way the birds are reared in South American countries due to climatic conditions. Open houses and the use of natural ventilation generally provide better air quality inside than houses used in temperate climate countries. Thus, rearing requirements need to be adapted in trade agreements. There is a clear opportunity for researchers in South American countries to design better housing and handling facilities for this region and to address animal welfare issues properly (Fraser, 2008).

\section{BRAZILIAN CONSUMER SURVEY}

In order to find out about consumer attitudes in Brazil, a special survey was carried out among nearly one thousand e-mail users using an on-line questionnaire containing questions related to animal welfare. The e-mail database used was a social network of students of a research group and their families and friends. It was sent to the group, which was asked to replicate it within their group lists. The e-mail user was not identified and the questions included age, income level, education level, job, chicken meat consumption, and if he/she was willing to pay more for the meat of chickens produced under better welfare conditions. It was also asked if the person had any knowledge on animal welfare, on animal welfare legislation, and on environmental issues, such as impacts on the planet, including recycling. The answers regarding specific items of welfare issues could be answered as "yes", "no", or "I don't know". Data were evaluated using cluster analysis.

\section{Consumers' survey results}

Eight of the total e-mails sent were answered. Out of the total of respondents, $75 \%$ were students or professionals, $19 \%$ were involved in animal husbandry and $6 \%$ were government employees working at administrative level. Among the respondents, 78\% bought chicken meat from known sources, 58\% changed their habits and consumed organic, ethical or similar products, $79 \%$ stated that the broilers should have some "legal" protection during production, and $96 \%$ stated that the bird should not suffer during rearing. Education level was positively correlated ( $p=$ 0.046 ) to the answers related to previous knowledge on animal welfare issues, and $70 \%$ of the answers stated that chicken meat was not the most consumed meat either at home or outside. It must be mentioned that in most Latin American countries the most consumed meat is beef.

Cluster analysis indicated that the consumers willing to pay more for the meat of broilers reared in farms with high welfare standards were grouped according to knowing how broilers are produced, recycling, being worried about environmental issues, and willing to protect broilers from suffering or abuse. The correlations among questionnaire answers are shown in Figure 3. 
Silva RBTR, Nääs IA, Broom DM, O’Driscoll K

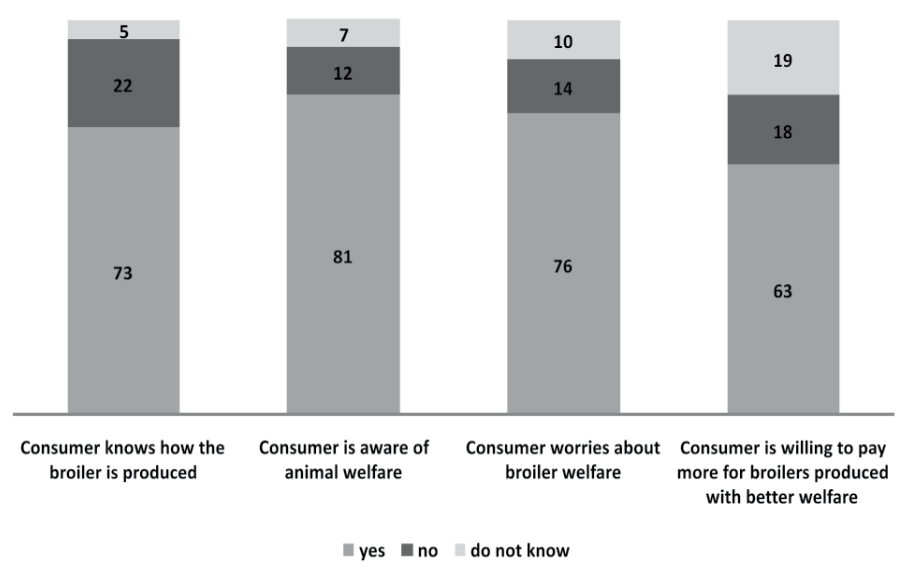

Figure 3 - Consumer scenario in relation to broiler welfare in Brazil.

\section{NORMS AND REGULATIONS IN SOUTH AMERICAN POULTRY PRODUCING COUNTRIES}

Brazil is the largest poultry producer in the region, followed by Argentina, Chile and Bolivia, and yet the review of the norms and regulations regarding animal welfare has been taken seriously for only a few years ago. As part of the production is exported, farmers have adopted international trade rules, such as those determined by GLOBALGAP. The norms most frequently complied are those published in good practice manuals, which include clear animal welfare requirement. Like the other countries in the region, Brazilian legislation is outdated and does not specifically address animal welfare issues (Brasil, 1998; Dias, 2000). In the last two years, national organizations have strived to develop new rules, norms and regulations, including details of how to improve farm animal welfare, and some agri-businesses companies have made internal policy changes as to how their animals are reared. In 2007 a study group led by OIE was established in the Americas gathering representatives from different countries, with the purpose of establishing appropriate animal welfare regulations. In August 2008 this group met for the first time in Panama to start building guidelines for all countries of that region. The discussed and agreed topics, included:

- Animal welfare is a relevant component to ensure adequate flock health and performance;

- Animal welfare is a relevant aspect of public opinion, with significant impact on consumers' demands;

- The OIE has included animal welfare in its Strategic Plan and the organization is in charge of coordinating the development of global standards;

1 - This includes GLOBALPGAP or other private company norms, as well as fast food restaurants norms.
Poultry Welfare Scenario in South America: Norms and Regulations

- The concerns of farmers with private norms ${ }^{1}$, which do not necessarily agree with the OIE standards, have a negative impact on the production and trade of animal products. This is mostly related to the cost of implementing welfare norms and regulations;

- The priority in animal welfare issues related to beef and dairy cattle production will prevail over other species (this is a contradiction because broiler production is where most of the welfare problems related to rearing are identified).

From the above list it is clear that awareness of the understanding of this issues is rather incipient, and the proposal made evidently shows that the regional delegates have neglected the subject. Brazilian legislation does not specifically address animal welfare issues and producers involved in the international meat export market rely on standards and information found in good practice codes published by extension and research institutions (Brasil, 2001; Dias, 2000; Amaral et al., 2006), on international private certification agencies (GLOBALGAP, 2009), and on currently available literature (Silva, 2001; Cony \& Zocche, 2004; Aradas \& Nääs, 2005). A study was carried out to compare Brazilian welfare regulation in poultry, with the EU, USA and Australia, and the results indicated that Brazilian regulation attained the lowest score for all types of demands related to rearing, handling and transportation (Silva, 2007; Silva et al., 2009). Scores were given to each specific demand relative to its requirement in international codes, in a 1 to 5 scale, as follows: $1=$ very poor (no norms regarding that subject as compared to international standards), $2=$ poor (there are a few norms and little or no compliance), $3=$ intermediate (there are norms for at least half of the international standards), $4=$ good (there are several norms and regulations regarding several production aspects and good degree of compliance), 5=very good (codes and regulations totally agree with the international norms and there is a high degree of compliance). Instead of following a specific legislation or norm, descriptions, details or measurements concerning each management or procedure are often used. A comparative analysis of the mean score values was made to evaluate the performance of each country or economic block in terms of addressing welfare legislation both in broiler and swine production, relative to the chosen types of demand (Tables 1 and 2). The results indicate that there is an urgent need to invest in the update of animal welfare norms and legislation in order to maintain the international competitiveness of South America. 
Table 1 - Scores of norms concerning broiler production, rearing environment and traceability management.

\begin{tabular}{lcccc}
\hline Items of norm that were & \multicolumn{3}{c}{ Norms and regulations } & \multirow{2}{*}{ Average } \\
\cline { 2 - 4 } compared & MBPB & GLOBALGAP & EHS & \\
\hline Production management & 4.5 & 3.5 & 3.0 & 3.7 \\
Environmental management & 4.0 & 3.5 & 4.0 & 3.8 \\
Traceability & 1.5 & 3.5 & 4.0 & 3.0 \\
Average & 3.3 & 3.5 & 3.7 & 3.5 \\
\hline
\end{tabular}

$\mathrm{MBPB}=$ Brazilian manual of good practices; GLOBALGAP= International trade code; EHS=Environmental, Health, and Safety Guidelines.

Table 2 - Scores concerning the presence of items related to rearing conditions, management and welfare issues.

\begin{tabular}{|c|c|c|c|c|}
\hline \multirow{2}{*}{$\begin{array}{l}\text { Items related to rearing } \\
\text { conditions, management } \\
\text { and welfare }\end{array}$} & \multicolumn{3}{|c|}{ Norms and regulations } & \multirow{2}{*}{ Average } \\
\hline & MBPB & GLOBALGAP & EHS & \\
\hline Housing and environment & 4.5 & 4.0 & 4.0 & 4.1 \\
\hline Density in flock & 4.5 & 4.0 & 0.0 & 2.8 \\
\hline $\begin{array}{ll}\text { Ventilation } & \text { and } \\
\text { temperature control } & \end{array}$ & 4.0 & 4.5 & 4.5 & 4.3 \\
\hline Light control & 3.5 & 4.5 & 3.5 & 3.8 \\
\hline Bedding & 4.5 & 4.0 & 3.5 & 4.0 \\
\hline Feeding and water & 3.5 & 3.5 & 4.0 & 3.6 \\
\hline Health control & 4.5 & 4.5 & 4.0 & 4.3 \\
\hline $\begin{array}{l}\text { Bird collection } \\
\text { transportation }\end{array}$ & 4.5 & 4.5 & 2.0 & 3.6 \\
\hline Welfare & 2.0 & 3.0 & 3.5 & 2.8 \\
\hline Average & 3.9 & 4.0 & 3.2 & 3.7 \\
\hline
\end{tabular}

$\mathrm{MBPB}=$ Brazilian manual of good practices; GLOBALGAP = International trade code; EHS=Environmental, Health, and Safety Guidelines. Source: Silva et al. (2009).

In terms of rearing conditions, the available documents present a summary of all necessary information on the rules to be followed. Despite having available material in current literature (Boivin et al., 1992; Dawkins, 2003), Brazilian and EU information on flock density establish specific measurements and indications, while other countries do not even mention this issue. There is information available on heat stress and ammonia control (Wathes et al., 2000; Cony \& Zocche, 2004; Aradas \& Nääs, 2005), but Brazilian manuals do not mention a limit for ammonia concentration or ambient temperature that may cause heat stress in poultry, or indicates an outcome indicator, such as panting that shows poor bird welfare due to high environmental temperature. The Environment, Health and Safety (EHS) guidelines show comparative data with DEFRA (U.K.) norms, but also does not mention any limits. Relative to light exposure, Brazilian norms only mention housing design in terms of natural lighting, and artificial lighting data are lacking. GLOBALGAP describes light measurements allowing the reader to easily follow and meet requirements. EHS does not present specific information on this matter, but refers to the DEFRA norms (DEFRA, 2008).
Litter use and management is mentioned in details in Brazilian and European manuals, but in the EHS, only litter cleaning is addressed, and does not specify litter materials or parasite or fungi control, as the Brazilian and GLOBALGAP norms do. Feed and water quality and availability are well described, and all critical points are mentioned in the EU manuals. Brazilian norms follow the rules dictated by the Ministry of Agriculture, which are somewhat vague, while the USA follows the rules dictated by FAO. Regarding health questions all countries follow the OIE rules, but hygiene is not specifically explained in the US material. Poultry catching and transportation are discussed in the analysed documents of Brazil and of the European Union; however, they are barely mentioned in the US manuals. Welfare-related issues are well addressed in the US manuals and even in more details in the EU norms; however, neither in the GLOBALGAP nor in Brazilian manuals the matter is properly mentioned or discussed.

\section{FINAL REMARKS}

It is fully recognized in most South American countries that all individuals involved in the business of rearing animals for food have a huge responsibility, making sure that their animals are housed, raised, transported and processed with care, but there are no references to the humane treatment of animals. In addition, the significant developments in animal welfare science are rarely acknowledged. Livestock companies have accepted, with some restrictions due to the increase in production costs and consequent loss of competitiveness in the international market, the fact that they will need to be in the forefront of the welfare issues in their business. They also accept that they will need to increasingly demonstrate accountability to their customers and consumers, for whom farm animal welfare is of critical importance. Governments and regulation agencies have delayed the establishment of proper regulations due to the political pressure of the companies. However, the OIE study group for the Americas is promoting the debate on animal welfare and the use of scientific information on this and other aspects of sustainability.

\section{REFERENCES}

ABEF. 2008 Report. [cited 2009 jan 9]. Available from: www.abef. org.br.

Albright JL, Arave CW. The behaviour of cattle. Wallingford: CAB 
International; 1997.

Alimentos Argentinos. [cited 2009 jan 20]. Available from: http:// www.alimentosargentinos.gov.ar/0-3/revistas/r_38/cadenas/ Carnes_Produccion_avicola.htm.

Amaral AL, Lima GJMM, Silveira PRS, Klein CS, Paiva DP, Martins F, Kich JD, Zanella JRC, Fávero J, Ludke JV, Bordin LC, Miele M, Higarashi MM, Móres N, Dalla Costa OA, Oliveira PAV, Bertol TM, Silval VS. Good practices for producing swine. Concórdia. 2006. [cited 2009 jan 10]. Available from: www.cnpsa.embrapa.br.

APA.[cited 2009 jan 20]. Available from: http://www.apa.cl/index/ catalogo.

Aradas MEC, Nääs IA. Thermal environment in broiler houses using two bird densities under tropical conditions. Agricultural Engineering International 2005; 7:1-10.

ASPROCER. [cited 2009 jan 20]. Available from: http:// www.asprocer.cl/index/download.asp \% 3Ftipo \% 3D4\%26 carpeta\%3Darchivos_estadistico\%26id_archivo\%3D34+ produccion+pollo+Colombia.

Bellaver C, Bellaver IH. Livestock production and quality of societies' life in transition economies. Livestock Production Science 1999; 59:125-135.

Boivin X, Le Neindre P, Chupin JM. Establishment of cattle - human relationships. Applied Animal Behaviour Science 1992; 32:325 -335 .

Brasil. Law n.9605, 12th of February of 1998. In: Gomes, LF. Constituição Federal Constitution: crime code. 3rd ed. São Paulo: Ed. Ver. Tribunais, 2001. p. 1248.

Broom DM. The use of the concept animal welfare in European conventions, regulations and directives. Uppsala: SLU Services; 2001. p.148-151.

Broom DM. Does present legislation help animal welfare? Landbauforschung Völkenrode 2002; 227:63-69.

Broom DM. The evolution of morality and religion. Cambridge: Cambridge University Press; 2003.

Broom DM. Introduction - Concepts of animal protection and welfare including obligations and rights. In: Animal Welfare. Ethical Eye Series. Strasbourg: Council of Europe Publishing; 2006. p.13-28.

Broom DM, Fraser AF. Domestic animal behaviour and welfare. 4th ed. Wallingford: $C A B \mid ; 2007$.

Cony AV, Zocche AT. Broiler' management. In: Mendes AA, Nääs IA, Macari M. Broiler production. Campinas: FACTA; 2004. cap. 8, p. 118-136.

Dawkins MS. What makes free-range broiler chickens range? In situ measurement of habitat preference. Animal Behaviour 2003; 65:01-10.

Dawkins MS, Cook PA, Whittingham MJ, Mansell KA, Harper AE. What makes free-range broiler chickens range? In situ measurement of habitat preference. Animal Behaviour 2003; 66:1-10.

DEFRA. Department For Environment, Food And Rural Affairs. 2007 Report. [cited 2007 aug 22]. Available from: www.defra.gov. uk/search/.

Dias EC. The legal protection of animals. Belo Horizonte: Mandamentos; 2000.

Duncan IJH, Petherick JC. The implications of cognitive processes for animal welfare. Journal of Animal Science 1991; 69:50225071.

EL COMERCIO.[cited 2009 jan 20].Available from: http://www. elcomercio.com. pe/ediciononline/html/2008-08-25/produccionpollo-crecio-69-entre-enero-y-julio-y-agosto-creceria-58.html.

EUREPGAP. The global partnership for safe and sustainable agriculture.[cited 2005 nov 16]. Available from: http://www. eurepgap.org/Languages/English/index_html.

FENAV. [cited 2009 fev. 6]. Available from: http://encolombia.com/ veterinaria.

FENAVI. [cited 2009 jan. 15]. Available from: http://www.fenavi. com.

Fraser D. Applying science to animal welfare standards. Proceedings of the Global Conference on Animal Welfare: an OIE; 2004; Paris. France.p. 121-127. 2004.

Fraser D. Towards a global perspective on farm animal welfare. Applied Animal Behavior Science 2008; 113:330-339.

GLOBALGAP. The global partnership for good agricultural practice. [cited 2009 fev 29]. Available from: http://www.globalgap.org/ Languages/English/.

Mc Inerney J. Animal welfare, economics and policy: Report on a study undertaken for the farm \& animal health economics. London: DEFRA; 2004. 68p.

Mitchell L. Impact of consumer demand for animal welfare on global trade. 2001. [cited 2009 jan 6]. Available from: http://www. ers.usda.gov/Publications/WRS011/.

Pawelek R, Croney D. Understanding and addressing issues related to the well-being of livestock. 2003. [cited 2007 jun 8]. Available from: www.eesc.oregonstate.edu.

Puma MC, Xin H, Gates RS, Burnham DJ. An instrumentation system for studying feeding and drinking behaviour of individual poultry. Applied Engineering in Agriculture 2001; 17:365-374.

Silva IJO. Poultry production ambient in tropical conditions. Engenharia Agrícola 2001; 2:150-214,

Silva JG, Genofre F, Lavoreti W. Special criminal laws annotated. Campinas: Millenium; 2001. p.35-82.

Silva RBTR. Animal production: Brazilian welfare legislation scenario [dissertation]. Campinas (SP): UNICAMP;2007. 
Silva RBTR, Nääs IA, Moura DJ. Broiler and swine production: animal welfare legislation scenario. Scientia Agricola 2009; 66:713-720.

Snowdon CT. The meaning of research in animal behavior. Estudo de Psicologia 1999; 4:365-373.

Van Horne PLM, Achterbosch TJ. Poultry welfare and EU standards. World's Poultry Science Journal 2008; 64:40-51.

Wathes $\mathrm{CM}$, Jones JB, Kristensen $\mathrm{HH}$, Jones EKM, Webster AJF. Aversion of pigs and domestic fowl to atmospheric ammonia. Transactions of the ASAE 2000; 45:1605-1610. 


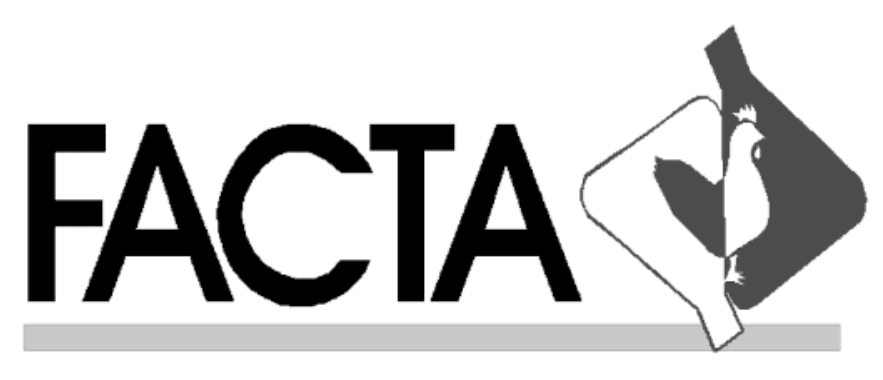

\section{Publicações FACTA}

Anais da Conferência APINCO'98

Anais da Conferência APINCO'99 (2 vol)

Anais da Conferência APINCO'00 (2 vol)

Anais da Conferência APINCO'02 (1 vol)

Anais da Conferência APINCO'03 (1 vol)

Anais da Conferência APINCO'05 (2 vol)

Anais da Conferência APINCO'06 (1 vol)

Anais da Conferência APINCO'07 (1 vol)

Anais da Conferência APINCO'08 (1 vol)

Anais da Conferência APINCO'09 (1 vol)

IX Conferência Internacional de Coccidiose Aviária

IX Conferência Internacional de Coccidiose Aviária (CD)

Simpósio FACTA de Postura Comercial

Fisiologia Aviária

Doenças das Aves

Produção de Frangos de Corte

Manejo de Matrizes de Corte

Seminário Nacional de Incubação de Ovos: Novas Tecnologias (CD)

Seminário Latino Americano de Abate e Processamento de Frangos de Corte (CD) 